\title{
SYNTHESIS AND CHARCTERIZATION OF SILVER NANOPARTICLES FROM THE LEAF EXTRACT OF MALACHRA CAPITATA (L.)
}

\author{
G.M. Srirangam ${ }^{1}$ and K. Parameswara $\mathrm{Rao}^{2 *}$ \\ ${ }^{1}$ Department of Zoology and Paramedical \& Hospital Administration, \\ Andhra Loyola College, Vijayawada- 520008, India \\ ${ }^{2}$ Department of Chemistry, Andhra Loyola College, Vijayawada- 520008, India \\ *E-mail: kp.rao1982@gmail.com
}

\begin{abstract}
Silver nanoparticles display unique physical and biological properties which have attracted intensive research interest because of their important medical applications. In this study silver nanoparticles (AgNPs) were synthesized for biomedical applications by a completely green biosynthetic method using Malachra Capitata(L.) leaf n-hexane extract.The prepared Ag NPs were characterized using UV-Visible, scanning electron microscopy/ energy dispersive X-ray spectroscopy (SEM/EDX), selected Area Diffraction Pattern (SAED) and Transmission Electron Microscopy (TEM), X-ray powder diffraction (XRD) and FTIR techniques. The UV-visible spectroscopic analysis showed the absorbance peak at $425 \mathrm{~nm}$, which indicates the synthesis of silver nanoparticles. The average particle diameter as determined by TEM was found to be $35 \pm 5 \mathrm{~nm}$. The XRD pattern showed the the face center cubic (fcc) silver nanoparticles and confirmed that these nanoparticles are crystalline in nature.EDX analysis also exhibits the presence of silver element. The transmission electron micrographs showed the formation of polydispersed nanoparticles. During this study, the antimicrobial activities of green synthesized AgNPs were evaluated against various microorganisms. This work proved the capability of using biomaterial towards the synthesis of silver nanoparticles by adopting the principles of green chemistry.

Keywords: Malachra Capitata (L.) leaf extract, Silver Nanoparticles, Characterization, Antimicrobial studies.
\end{abstract}

(c) RASĀYAN. All rights reserved

\section{INTRODUCTION}

In the recent years, silver nanoparticles(NPs) have received the enormous attention of the researchers due to their extraordinary defense against a wide range of microorganisms and also due to the appearance of drug resistance against commonly used antibiotics ${ }^{1,2}$. Plant-mediated synthesis is gaining cost-effective, economic, eco-friendly and aiding to scale up the synthesis of nanoparticles. The development of cost efficient and ecologically benign methods of synthesis of nanomaterials still remains a scientific challenge as metal nanoparticles are of use in various catalytic applications, viz electronics, biology and biomedical applications, material science, physics, environmental remediation fields ${ }^{3}$. Novel methods of ideally synthesizing NPs are thus being thought which are formed at ambient temperatures, neutral $\mathrm{pH}$, low costs and environmentally friendly fashion. Keeping these goals in view nanomaterials have been synthesized using various routes. As a wide range of metabolites is presented in the plant products/extracts, nanoparticles produced by plants are more stable and the rate of synthesis is faster in comparison to microorganisms. Thus, the advantages of using plant and plant-derived materials for biosynthesis of metal nanoparticles have instigated researchers to investigate mechanisms of metal ions uptake and bio-reduction by plants and to understand the possible mechanism of metal nanoparticle formation in and by the plants ${ }^{4-7}$.The antimicrobial effects of silver ion or salts are well known, but the effects of Ag nanoparticles on microorganisms and antimicrobial mechanism have not been revealed clearly. Stable Ag nanoparticles were prepared and their shape and size distribution characterized by particle characterizer and transmission electron microscopic study. 
Malachra capitata is belonging to family Malvaceae. It is very commonly seen near annual or perennial, erect herbs orundershrubs, to $1.5 \mathrm{~m}$ high; Leaves alternate, orbicular or ovate, 3-5 angled or lobed, cordate at base, crenate to serrate at margin, obtuse or rounded at apex, 3-14 x 4-20 cm, velutinous with stellate and simple hairs on both surfaces, glabrescent, 5- nerved at base; petioles $2-8 \mathrm{~cm}$ long; stipules 1-2 $\mathrm{cm}$ long, filiform, rarely forked, hispid (Fig. 1). Rao et al. published their results on different materials in the earlier studies ${ }^{8-60}$. The plant is used medicinally; especially roots and leaves are in some regions used as medicines. The root of the Malachra capitata (L.) is traditional remedies for the many disease conditions. As part of our contributions to the growing interest of bio-mediated synthesis of AgNPs, we report for the first time an inexpensive synthesis of AgNPs by a green route at room temperature, stabilized in situ using Malachra capitata $(L$. ) leaf extract and tested for their anti-microbial activity.

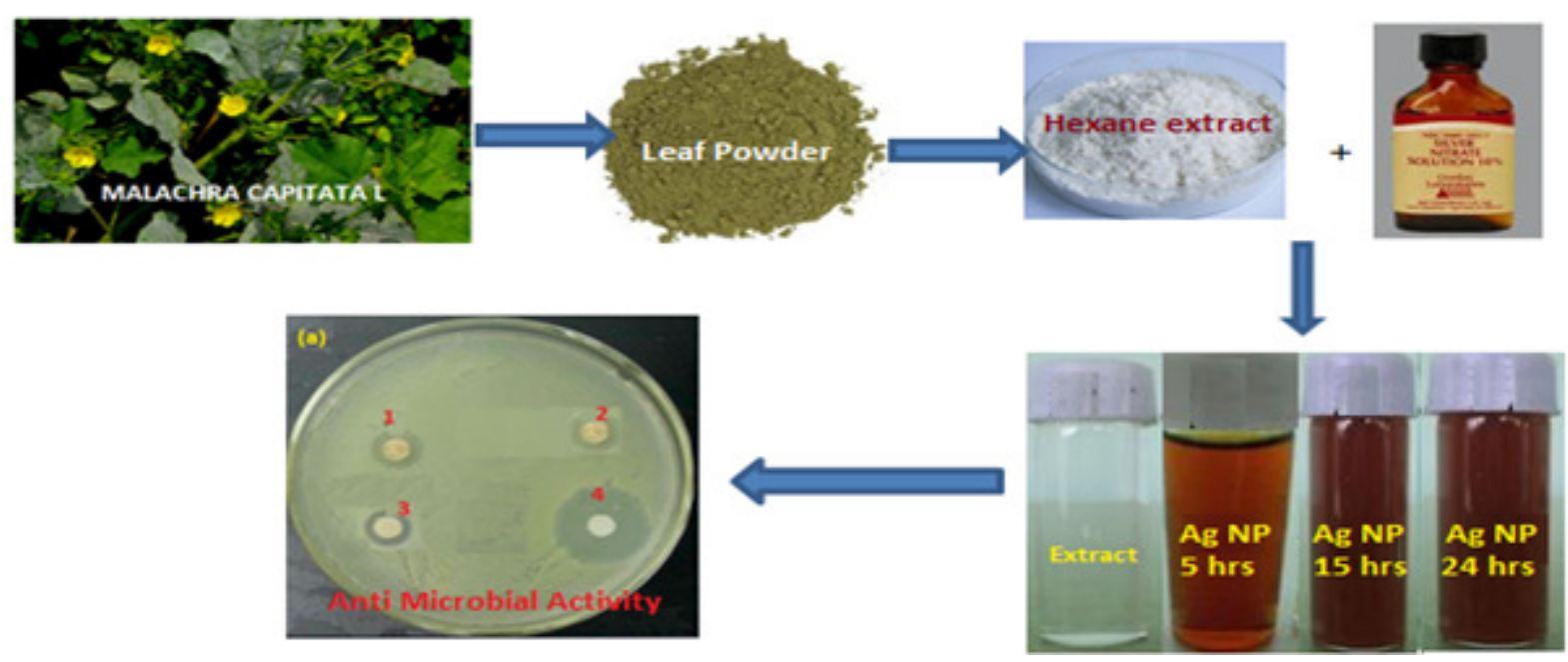

Fig.-1: Graphical representation of green and chemical syntheses of silver nanoparticles using Malachra Capitata $(L$.)leaf and evaluation of their anti-microbicidal activities against various bacterial strains

\section{Chemicals}

\section{EXPERIMENTAL}

All chemicals and reagents had an analytical grade. Silver nitrate, n-hexane with high purity purchased from Sd Fine Chemicals, India.

\section{Apparatus and Instruments}

The conventional Soxhlet extraction apparatus was used, which consists of a condenser, a Soxhlet chamber, and an extraction flask. The extractor thimble was permeable one with $44 \mathrm{~mm}$ internal diameter and $200 \mathrm{~mm}$ external length. The rotary evaporator was used for evaporation of the solvent of extracted material.

\section{Sampling and Extraction}

The fresh sample of Malachra capitata (L.) leaf powder was collected at the end of May in local Area agricultural fields. The samples were ground in grinding mill with a particle size of less than $2 \mathrm{~mm}$ (Fig.1). The raw ground sample was sealed and stored in desiccators for further usage. 25 gm homogenized Datura Metal root sample was extracted with $100 \mathrm{ml}$-hexane for 1 hour. The extraction was repeated for 3 times and then the extracts were filtered through Whatman filter paper no 42. Then the filtered extract was stored in a refrigerator at $4^{\circ} \mathrm{C}$ for further use in the synthesis of silver nanoparticles.

\section{Synthesis of AgNPs}

The synthesis of silver nanoparticles was done by mixing Malachra Capitata(L.) leaf extract and $1 \mathrm{mM}$ of aqueous silver nitrate solution $\left(\mathrm{AgNO}_{3}\right)$ in the ratio 1:20 added to plant extract ethanolic solution and 
heated at $90 \pm 2^{\circ} \mathrm{C}$ until the color of the solution was changed from colorless to thick brown. Resulted solutions were settled for 24 hours in dark to avoid any further photochemical reactions, after that the solution was centrifuged at $5000 \mathrm{rpm}$ for 10 minutes with a magnetic shaker. The supernatant was discarded and the pellet was air dried in the incubator. The bio-reduction of $\mathrm{Ag}^{+}$ions was monitored by periodic sampling by the UV spectrophotometer. The AgNPs in the freeze-drying bottle were suspended in ultrahigh purity water for all characterization methods and antibacterial assays. During biosynthesis of silver nanoparticles when leaf extract was added to $100 \mathrm{ml}$ of $1 \mathrm{mM} \mathrm{AgNO}_{3}$ salt, the ionization took place as follows:

$$
\begin{gathered}
\mathrm{AgNO}_{3}(\mathrm{aq}) \leftrightarrow \mathrm{Ag}^{+}(\mathrm{aq})+\mathrm{NO}_{3}^{-}(\mathrm{aq}) \\
\mathrm{e}^{-}+\mathrm{Ag}^{+} \rightarrow \mathrm{Ag}
\end{gathered}
$$

It is assumed that the silver ions enter inside the plant cell via the $\mathrm{H}^{+} \mathrm{ATPase}$ protein embedded in the thylakoid membrane by an electrogenic pump $^{61}$. Synthesis of silver nanoparticles is a photochemical reaction.

\section{Characterization}

\section{UV-visible spectroscopy}

The formation of dark brown color during the synthesis was confirmed as the formation of AgNPs. The reduction of the pure AgNPs was recorded under UV-visible spectroscopy using ELico model UVvisible spectrophotometer between $300 \mathrm{~nm}$ and $700 \mathrm{~nm}$. The UV-visible spectra of the plant leaf extract and silver nitrate solution were also recorded.

Stability of AgNPs- Time: The stability of AgNPs from Malachra Capitata(L.) leaf extract was recorded between $300 \mathrm{~nm}$ and $700 \mathrm{~nm}$ at different time intervals such as 1 hour, 5 hours, 10 hours, 10 hours, and 24 hours. The absorbance of the solutions was measured using Elico model UV-visible spectrophotometer results were given in Fig.-2.

Fourier Transform Infra Red (FTIR) analysis was done using Perkin ElemerSpectrum-1 and was used to identify the chemical constituents in the region of 400-4000 $\mathrm{cm}^{-1}$ of the Ag-NPs. X-Ray Diffraction (XRD) measurement: XRD measurements of Ag-NPs were cast into glass slides were done by Phillips PW 1830 instrument. The powdered Ag-NPs were uniformly spread and sputter coated with platinum in an ion coater for 120 seconds, then observed by SEM JEOL-JSM 6360 MODEL, JAPAN). Elemental analysis of the powdered Ag-NPs was conducted using Energy-Dispersive X-ray (EDX) detector (EDS, EDAX Inc., Mahwah, NJ, USA) attached to the SEM machine.

Transmission Electron Microscopy (TEM) analysis of Ag-NPs: The sample was first sonicated (Vibronics VS 80) for 5 minutes. Ag-NPs were loaded on carbon coated copper grids and the solvent was allowed to evaporate under Infra light for 30 minutes. TEM measurements were performed on Phillips modle CM 20 instrument, operated at an accelerating voltage at $200 \mathrm{kV}$. The antibacterial activity of the synthesized AgNPs was determined using disk diffusion method. Pure cultures of the microorganisms were subcultured on Mueller-Hinton agar. Each strain was swabbed uniformly onto individual agar plates using sterile cotton swabs. Sterile paper disks were placed on the agar plates, and $10 \mu \mathrm{L}$ of $100 \mu \mathrm{g} / \mathrm{mL}(\mathrm{w} / \mathrm{v})$ samples were applied to the disks. Gentamicin (30 $\mu \mathrm{g}$ per disk) was used as a control agent. All the plates were incubated at $35^{\circ} \mathrm{C}$ for $18-24$ hours.

\section{UV-visible spectroscopy}

\section{RESULTS AND DISCUSSION}

Malachra Capitata(L.) leaf (Fig.-1) n-hexane extract added with silver nitrate at $1 \mathrm{mM}$ showed a change in color from a white color to dark brown (Fig.-2). This was due to the excitation of surface plasmon resonance (SPR) by $\mathrm{AgNPs}^{5}$. AgNPs have free electrons, which give rise to SPR absorption band, due to the combined vibration of electrons of metal nanoparticles in resonance with the light wave ${ }^{6}$. The reduction of AgNPs in the aqueous solution of the silver complex during the reaction with the leaf extract of Malachra Capitata(L.) was confirmed by the UV-visible spectra. The $\mathrm{AgNO}_{3}$ solution and Malachra Capitata(L.) leaf aqueous extract alone did not show any peak between $300 \mathrm{~nm}$ and $600 \mathrm{~nm}$ (Fig.-2a). 


\section{Stability of silver nanoparticles}

AgNPs synthesis was also evaluated under UV-visible spectroscopy at different durations (1 hour-24 hours) (Fig.-2b) in order to study the stability of the formed nanoparticles. It was recorded that with increased contact time, the peak becomes sharper. The reaction had started within 1 hour, and the SPR showed a peak at $430 \mathrm{~nm}$. Thereafter, there was a shift in the peak from $435 \mathrm{~nm}$ at 5 hours and $435 \mathrm{~nm}$ at 24 hours also. The reaction ended at 24 hours with an absorption peak at $435 \mathrm{~nm}$ (Table-1). The sharper peak indicated the formation of monodisperse nanoparticles from the extract Malachra Capitata(L.) leaf.

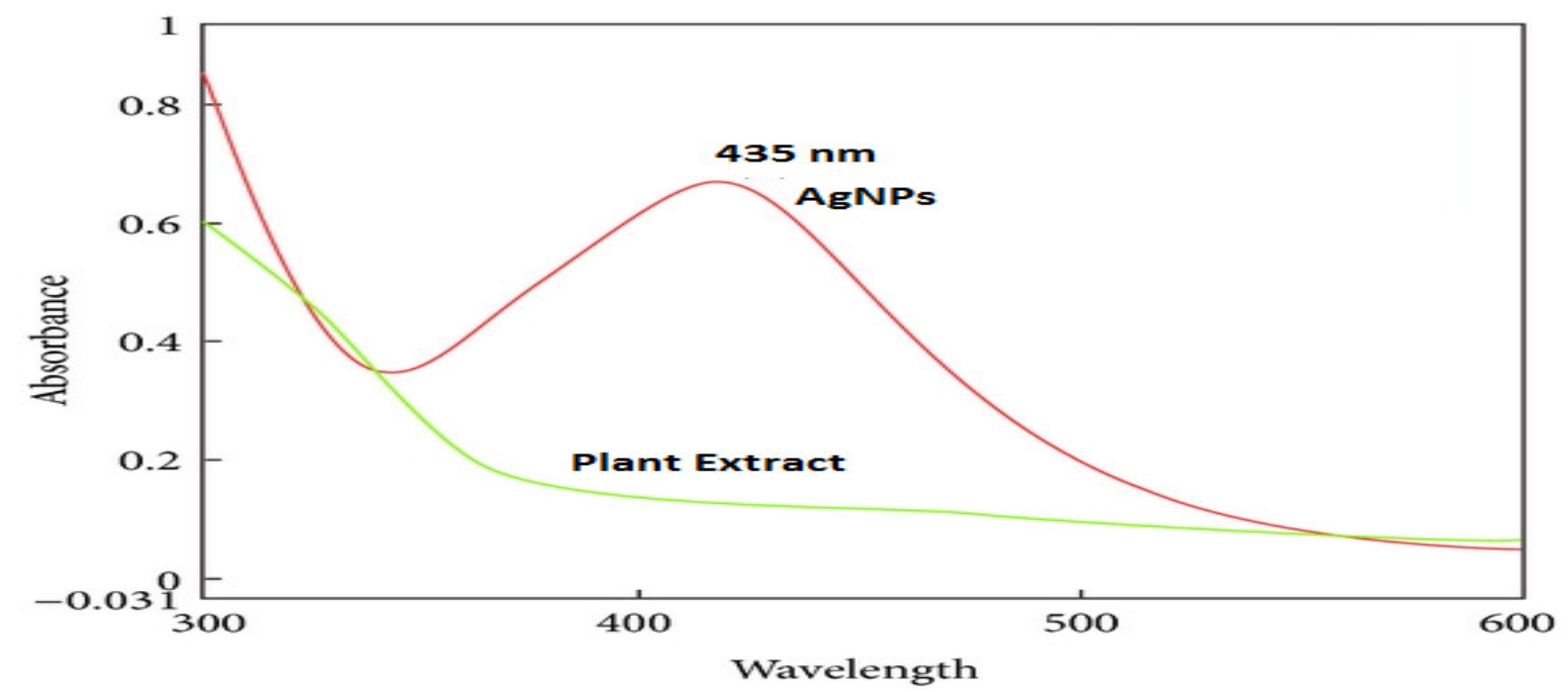

(a)

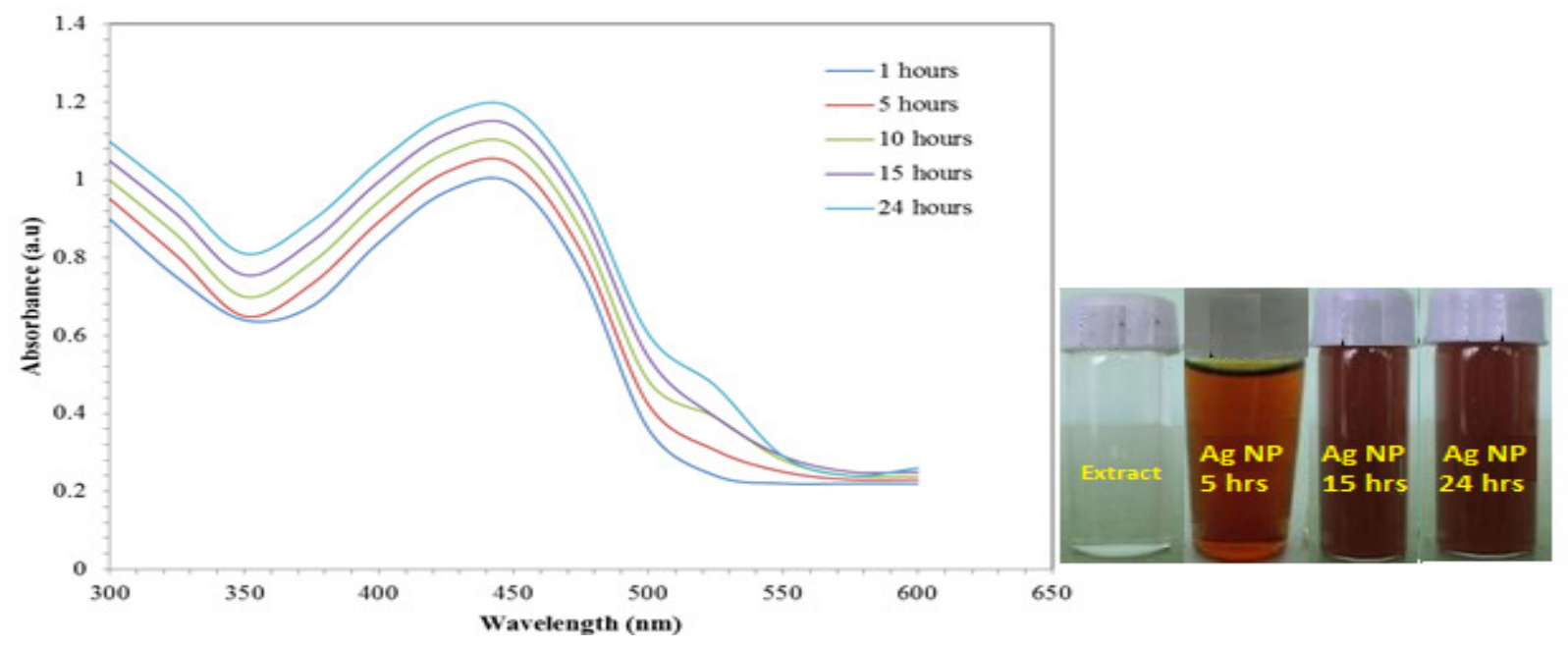

(b)

Fig.-2: (a): UV-Vis spectra of MalachraCapitata(L.) plant extract and AgNPs; (b): UV-Vis spectra of Malachra Capitata(L.) leaf silver nanoparticle stability studies (Left) and in right color change reaction during conversion of silver nanoparticle at different time intervals

Table-1: Stability of Ag NPs

\begin{tabular}{l|l|l}
\hline S. No. & Hours & nm (wavelength) \\
\hline 1 & 1 & 430 \\
\hline 2 & 5 & 435 \\
\hline 3 & 10 & 435 \\
\hline 4 & 15 & 435 \\
\hline 5 & 24 & 435 \\
\hline
\end{tabular}




\section{The XRD analysis}

XRD analysis showed distinct diffraction peaks and the Braggs reflections were observed in the XRD pattern at $2 \theta=34.54,46.9,62.0$ and 79.2 (Fig.-3). These Braggs reflections clearly indicated the presence of (111), (200), (220) and (311) sets of lattice planes and further on the basis that they can be indexed as face-centered-cubic (FCC) structure of silver nanoparticles formed in this present synthesis are crystalline in nature. The typical XRD pattern revealed that the sample contained a mixed phase (cubic and hexagonal) structures of silver nanoparticles. The average estimated particle size of this sample was 35 $\mathrm{nm}$ derived from the FWHM (full width at half maximum) of the peak corresponding to 111 plane $^{62}$.

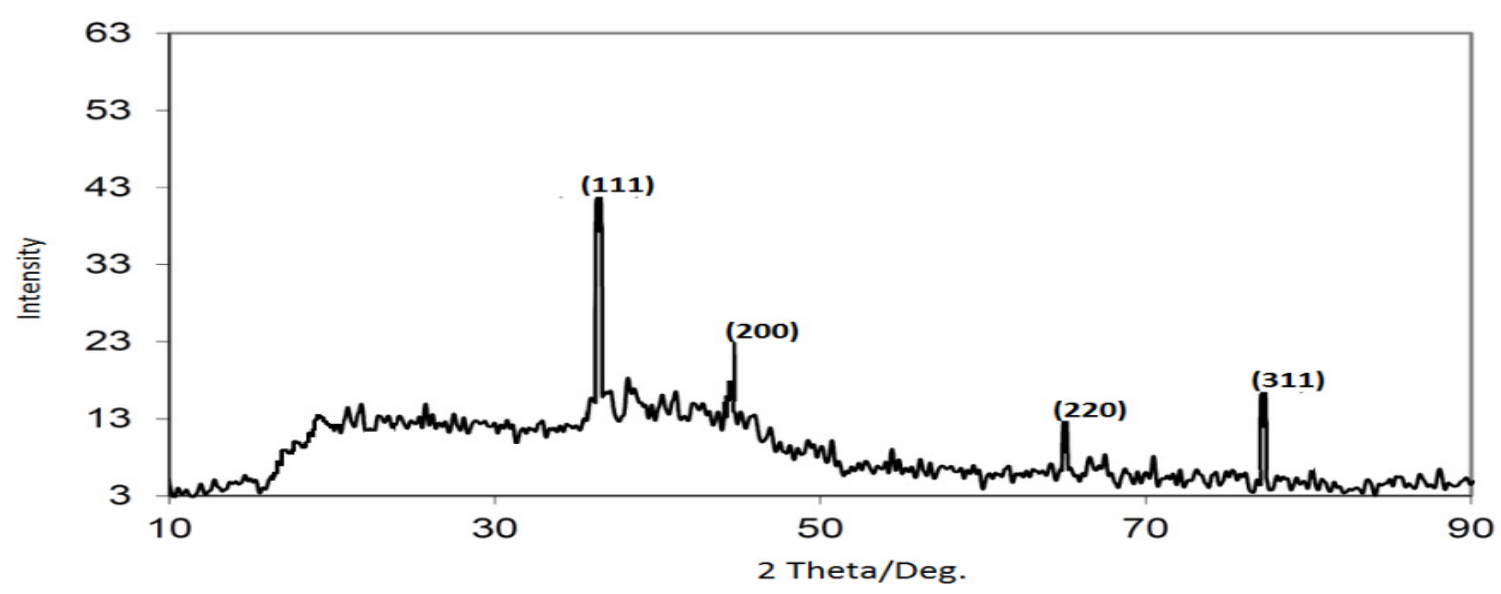

Fig.-3: X-ray diffraction pattern of synthesized Ag NPs

\section{SEM-EDX analysis}

SEM technique was employed to visualize the size and shape of silver nanoparticles. The SEM images of the AgNPs are shown in Fig.-4. The formation of silver NPs, as well as their morphological dimensions in the SEM study, demonstrated that the average size was 30- $35 \mathrm{~nm}$ with inter-particle distance. It is seen that AgNPs of different shapes were obtained in leaf extract being used as reducing and capping agents Malachra Capitata(L.) leaf extract formed approximately tubular and cuboidal AgNPs, respectively. This may be due to the availability of different quantity and nature of capping agents present in the leaf extract. EDX spectra recorded from the silver nanoparticles were shown in Fig.-4. From EDX spectra, it is clear that silver nanoparticles reduced by M.Capitata $(L$.) have the weight percentage of silver as $70.36 \%$.
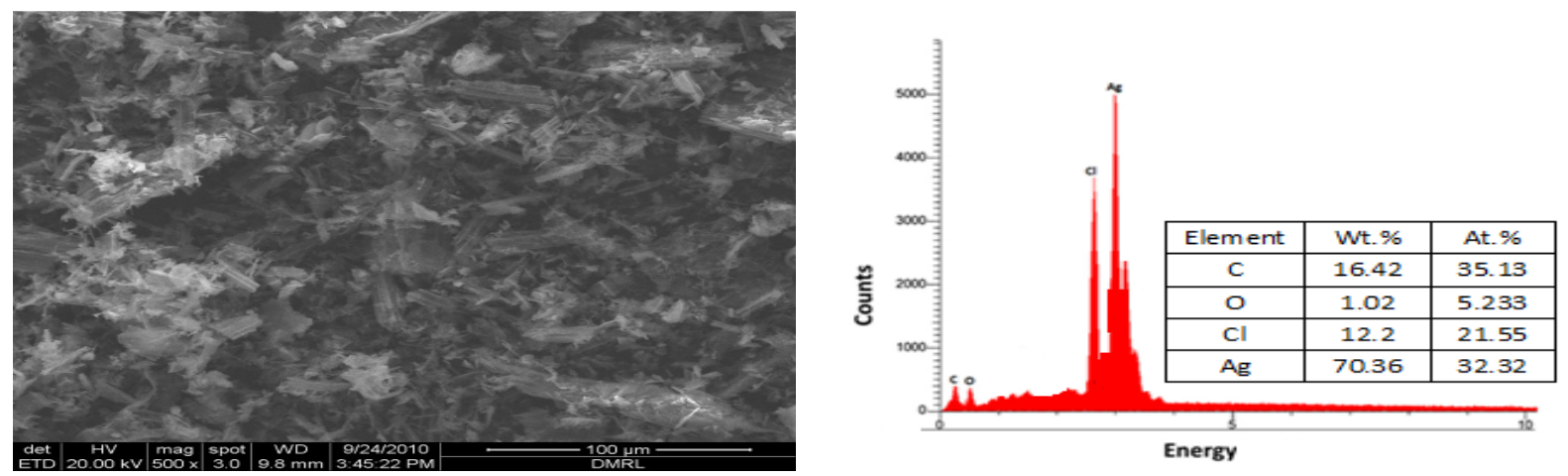

Fig.-4: SEM micrograph of agents Malachra Capitata(L.) extract- AgNPs and corresponding EDX spectra

\section{FT-IR Analysis}

FTIR spectroscopy is useful for characterizing the surface chemistry ${ }^{63}$. FTIR spectrum of AgNPs revealed the possible biomolecules present in the leaf extract, which was accountable as the reducing agent for the 
silver ions and its interaction with the AgNPs. The IR spectrum showed an intense band at $3419.17 \mathrm{~cm}^{-1}$, which corresponds to the strong stretching vibrations of a hydroxyl group (-OH) of phenolic compounds ${ }^{64}$. The band at $1626.14 \mathrm{~cm}^{-1}$ reveals the presence of $\mathrm{C}=\mathrm{C}$ group ${ }^{65}$. The peak around 2900 $\mathrm{cm}^{-1}$ is attributed to the alkane stretching band. This indicated that secondary metabolites are involved in the synthesis of Ag-NPs. The peak at $2900 \mathrm{~cm}^{-1}$ indicates the presence of alkyl groups while 1100 $\mathrm{cm}^{-1}$ signifies the presence of $\mathrm{C}-\mathrm{O}$ functional groups. Alcohols have been reported to facilitate the reduction of silver ions to silver nanoparticles while they are oxidized to carbonyl compounds ${ }^{66}$.

\section{TEM Analysis}

The TEM image in Fig.-5 shows that the particles were polydispersed and mostly spherical. The particle size from histograms for the AgNPs suggests that the particles ranged in size from 30 to $35 \mathrm{~nm}$ with an average diameter of $35 \mathrm{~nm}$. The size distribution curve [(Fig.-5 (right)] shows that the particles are in the range 5-70 nm with average particle diameter of $\pm 5 \mathrm{~nm}$. Fig. -5 (inset) shows selected area electron diffraction pattern (SAED) of the silver nanoparticles. SAED spots that corresponded to the different crystallographic planes of face-centered cubic (fcc) structure of elemental silver.
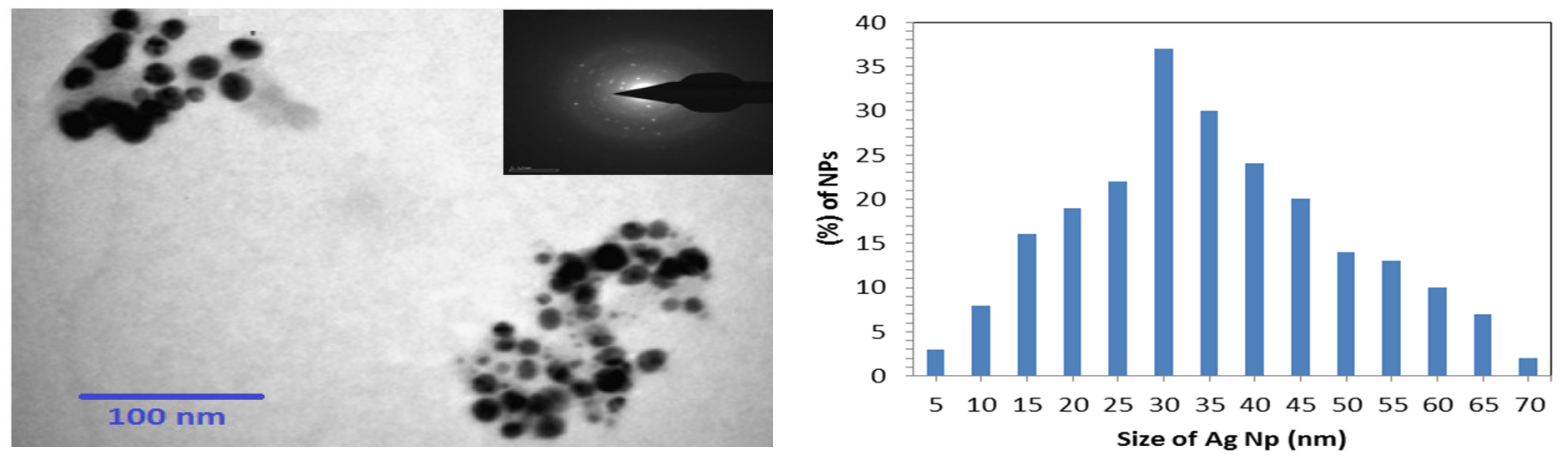

Fig.-5: TEM micrographs of the synthesized silver nanoparticles [inset SAED image] and particle size distribution

\section{Anti-bacterial Activity}

The antibacterial activity of synthesized silver nanoparticles was investigated against four different types of bacterial strains like Bacillus subtillis, Micrococcus Luteus, Staphylococcus aureus and Pseudomonas aeruginosa (Fig.-6) showed excellent antibacterial activity against all tested bacterial strains at the volume of $40 \mu \mathrm{L} /$ well. The zone of inhibition (in $\mathrm{mm}$ ) ranges identified as 21 for Bacillus subtillis, 19 for Pseudomonas aeruginosa, 17 Staphylococcus aureus, and for Micrococcus Luteusis 14. Based on inhibition zones around the discs, the antimicrobial activities were measured saturated with synthesized silver nanoparticle. The diameters of the inhibition zones for the all tested pathogens are listed in Table2.Thus, our results show that AgNPs synthesized using n-hexane extract of leaf extract nanoparticles have potential bacterial activity against four bacteria's.
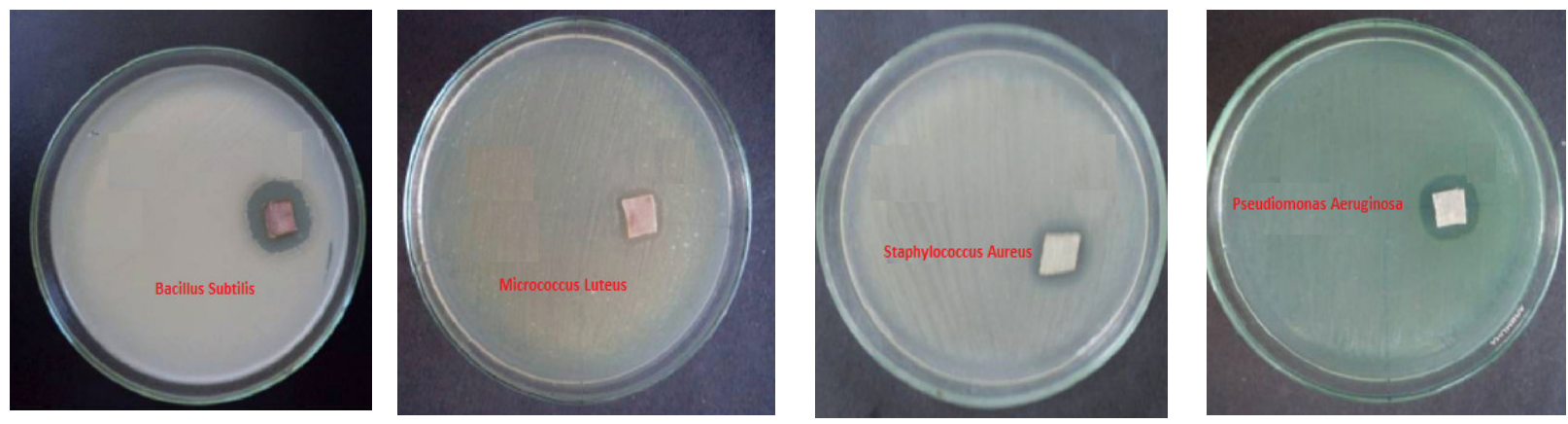

Fig.-6: Showing antibacterial activity of AgNPs of MalachraCapitata(L.) leaf extract against Bacillus subtillis, Micrococcus Luteus, Staphylococcus aureus and Pseudomonas aeruginosa 
RASĀYAN J. Chem.

Vol. 10 | No. 1 |46-53 | January - March | 2017

Table-2: Zone of Inhibition of selected microbial cultures with Ag NPs

\begin{tabular}{l|c}
\hline Bacteria & Zone of Inhibition (mm) \\
\hline Bacillus subtillis & 21 \\
\hline Micrococcus Luteus & 17 \\
\hline Staphylococcus aureus & 19 \\
\hline Pseudomonas aeruginosa & \\
\hline
\end{tabular}

\section{CONCLUSION}

In this study, Ag NPs were synthesized by an eco-friendly and convenient method using agents Malachra Capitata (L.) leaf n- hexane extract at ambient temperature. Malachra Capitata(L.) leaf n- hexane extract has been used as a reducing agent for the synthesis of silver nitrate into silver nanoparticles. Green synthesized silver nanoparticles are confirmed by a color change which was monitored quantitatively by UV-Vis spectroscopy at $435 \mathrm{~nm}$. Further characterization with SEM and TEM analysis shows the spherical, polydisperse Ag NPs of particle size ranging from 5 to $70 \mathrm{~nm}$ with an average size of $35 \mathrm{~nm}$. FTIR showed the structure, the respective bands of the synthesized nanoparticles and the stretch of bonds. Applications of such eco-friendly nanoparticles in bactericidal, wound healing and other medical applications, makes this method potentially exciting for the large-scale synthesis of other inorganic materials. Toxicity studies of silver nanoparticles on human pathogen opens a door for a new range of antibacterial agents.

\section{REFERENCES}

1. V.K. Sharma, R.A. Yngard and Y. Lin, Adv. Coll. Inter. Sci., 145, 83 (2009).

2. A. Nel, T. Xia, L. Madler and N. Li,Science, 311, 622 (2006).

3. N. Ahmad and S. Sharma, Green Sust. Chem., 2(4), 141 (2012).

4. N. Ahmad, M. K. Alam, V. N. Singh and S. Sharma, J.Bionanosci., 3(2), 97 (2009).

5. S. Ponarulselvam, C. Panneerselvam, K. Murugan, N. Aarthi, K. Kalimuthu and

S. Thangamani, Asain Pac.J. Trop. Biomed., 2(7), 574 (2012).

6. M. Manopriya, B. Karunaiselvi andJ.A. John Paul,J. Nanomater. Biostruct., 6, 869(2011).

7. K. A. Deodhar, Asian J. Sci.Tech.,7(8), 3310 (2016).

8. K. Parameswara Rao, G.V. Ramana and M.C. Rao, Der Pharm. Lett., 8(13), 259 (2016).

9. M.C. Rao, O.M. Hussain, J. Alloys Compd., 491(1), 503 (2010).

10. M.C. Rao, J. Crys. Growth, 312(19), 2799 (2010).

11. K. Ravindranadh, M.C. Rao and R.V.S.S.N. Ravikumar, J. Luminesce., 159, 119 (2015).

12. M.C. Rao, K. Ramachandra Rao, Int. J. Chem.Tech Res., 6(7), 3931 (2014).

13. M.C. Rao, Optoelect. \& Adv. Mater (Rapid Commu.), 5, 85 (2011).

14. Sk. Muntaz Begum, M.C. Rao and R.V.S.S.N. Ravikumar, Spectrochim. Acta Part A: Mol. \& Biomol. Spec., 98, 100 (2012).

15. M.C. Rao, J. Optoelect. \& Adv. Mater., 13, 428 (2011).

16. M.C. Rao, O.M. Hussain, Eur. Phys. J. Appl. Phys., 48(2), 20503 (2009).

17. Sk. Muntaz Begum, M.C. Rao and R.V.S.S.N. Ravikumar, J. Inorg. Organometa. Poly. Mater., 23(2), 350 (2013).

18. MC Rao, J. Optoelect. \& Adv. Mater., 12, 2433 (2010).

19. M.C. Rao, O.M. Hussain, IOP Conf. Series: Mater. Sci. Eng., 2, 012037, (2009).

20. M.C. Rao, O. M. Hussain, Ind. J. Eng. Mater. Sci., 16, 335 (2009).

21. K. Ravindranadh, M.C. Rao, R.V.S.S.N. Ravikumar, J. Mater. Sci: Mater. Elect., 26, 6667 (2015).

22. M.C. Rao, Optoelect. \& Adv. Mater. (Rapid Commun.), 5(5-6), 651 (2011).

23. M.C. Rao, O.M. Hussain, Optoelect. \& Adv. Mater., 13(2-4), 1109 (2011).

24. MC Rao, J. Optoelect. Adv. Mater., 13(1-2), 72 (2011). 
RASĀYAN J. Chem.

Vol. 10 | No. 1 |46-53 | January - March | 2017

25. K. Ravindranadh, B. Babu, C.V. Reddy, J. Shim, M.C. Rao, R. Ravikumar, Appl. Mag. Reson. 46 (1), 1 (2015).

26. MC Rao, OM Hussain, Res. J. Chem. Sci., 1(7), 92 (2011).

27. M.C. Rao, Int. J. Chem. Sci., 10(2), 1111 (2012).

28. M.C. Rao, Optoelect. \& Adv. Mater. (Rapid Commun.), 6, 511 (2012).

29. P.V. Prasad, K. Ramachandra Rao, M.C. Rao, J. Mol. Struc., 1085, 115 (2015).

30. M.C. Rao, J. Optoelect. \& Adv. Mater., 13, 78 (2011).

31. M.C. Rao, Sk. Muntaz Begum, Optoelect. \& Adv. Mater. (Rapid Commun.), 6, 508 (2012).

32. MC Rao, Res. J. Rec. Sci., 2(3), 67 (2013).

33. K. Parameswara Rao, G.V. Ramana, M.C. Rao, Der Pharm. Lett., 8(10), 222 (2016).

34. M.C. Rao, Int. J. Chem. Tech. Res., 6(3), 1904 (2014).

35. M.C. Rao, Optoelect. \& Adv. Mater. (Rapid Commun.), 4, 2088 (2010).

36. M.C. Rao, O. M. Hussain, Optoelect. \& Adv. Mater. (Rapid Commun.), 6, 245 (2012).

37. K. Parameswara Rao, G.V. Ramana and M.C. Rao, Der Pharm. Lett., 8(15), 101 (2016.

38. M.C. Rao, K. Ravindranadh, Der Phar. Chem., 8, 243 (2016).

39. M.C. Rao, Res. J. Rec. Sci., 2 (3), 67 (2013).

40. M.C. Rao, K. Ravindranadh, A. Kasturi, M.S. Shekhawat, Res. J. Rec. Sci., 2(4), 1 (2013).

41. K. Parameswara Rao, G.M. Srirangam, G.V. Ramana and M.C. Rao, Rasayan J. Chem., 9(3), 393 (2016)

42. M.C. Rao, O.M. Hussain, Res. J. Chem. Sci., 1(7), 76 (2011).

43. M.C. Rao, J. Non-Oxide Glasses, 5, 1 (2013).

44. M.C. Rao, K. Ravindranadh, Der. Pharm. Che., 8(7), 74 (2016).

45. Sk. Muntaz Begum, K. Ravindranadh, M.C. Rao, R.V.S.S.N. Ravikumar, AIP Conf. Proc., 1536, 27 (2013).

46. M.C. Rao, O.M. Hussain , AIP Conf. Proc., 1447, 613 (2012)

47. P.V. Prasad, K. Ramachandra Rao, M.C. Rao, Int. J. Chem Tech Res. 7(1), 269 (2014).

48. S. Rajyalakshmi, K. Ramachandra Rao, M.C. Rao, Int. J. ChemTech Res., 9(1), 7 (2016).

49. T. Samuel, K. Ramachandra Rao, M.C. Rao, AIP Conf. Proc., 1728, 020080 (2016).

50. M.C. Rao, K. Ravindranadh, Mater. Res. Innov., 21(2), 102 (2017)

51. M.C. Rao, Int. J. Pure Appl. Phys., 6, 365 (2010).

52. K. Parameswara Rao, G.V. Ramana and M.C. Rao, Der Pharm. Lett., 8(14), 132 (2016).

53. M.C. Rao, K. Ravindranadh, J. Chem. Biolo. Phys. Sci., 4(1), 469 (2013).

54. M.C. Rao, Int. J. Mod. Phys., Conf. Series: 22, 355 (2013).

55. M.C. Rao, M.S. Shekhawat, Int. J. Mod. Phys., Conf. Series: 22, 576 (2013).

56. K. Parameswara Rao and M.C. Rao, Der Pharm. Lett., 8(15), 125 (2016).

57. M.C. Rao, K. Ravindranadh, J. Non Oxide Glasses, 5, 39 (2013).

58. M.C. Rao, J. Chem. Bio. Phy. Sci. Sec. C, 3(2), 1412 (2013).

59. M.C. Rao, Sk. Muntaz Begum, AIP Conf. Proc., 1447, 613 (2012).

60. K. Ravindranadh, M.C. Rao, Int. J. ChemTech Res., 9(4), 598 (2016).

61. E.O. Donatus and C.I. Ephraim, African J. Pharm. Pharmacology, 3(5), 277 (2009).

62. E. J. Mary and Inbathamizh, Asian J.Pharm.Clin. Res., 5(1), 1 (2012).

63. B.D. Chithrani,A.A. Ghazani andW.C.W. Chan,Nano Lett., 6, 662 (2006).

64. Y. He, Z. Du, H. Lv, Q.J.Z. Tang, X. Zheng, K. Zhang and F. Zhao,Int. J. Nanomedicine, 8, 1809 (2013).

65. J. Krithiga andM.B. Mary,Pharm Anal. Acta., 6, 427 (2015).

66. S. Ghosh, S. Patil, M. Ahire, R. Kitture andS. Kale, Int. J. Nanomed., 7, 483 (2012).

[RJC-1548/2017] 